\title{
Pelaksanaan Webinar Dengan Tema Implementasi Digital Marketing Dalam Menarik Minat Konsumen Di Era Pandemi COVID-19 Khususnya Di Desa Ketapang
}

\author{
Deris Dasmawan $^{\mathrm{a}}$, Kevin Afandi ${ }^{\mathrm{b}}$, Nusyifa Tassya Puspitasari ${ }^{\mathrm{c}}$, Septy Anggrelia ${ }^{\mathrm{d}}$, Krisna \\ Damayanti $^{\mathrm{e}}$, Jeni Astuti Ningrum ${ }^{\mathrm{f}}$, Viera Rahmaniasan ${ }^{\mathrm{g}, *}$, Nurholifah $^{\mathrm{h}}$ \\ ${ }^{\text {a }}$ Program Studi Ekonomi Pembangunan, Universitas Sultan Ageng Tirtayasa, Banten, Indonesia \\ ${ }^{\mathrm{b}}$ Program Studi PGSD, Universitas Sultan Ageng Tirtayasa, Banten, Indonesia \\ ${ }^{c}$ Program Studi Pendidikan Non Formal, Universitas Sultan Ageng Tirtayasa, Banten, Indonesia \\ ${ }^{\mathrm{d}}$ Program Studi Ilmu Komunikasi, Universitas Sultan Ageng Tirtayasa, Banten, Indonesia \\ ${ }^{\mathrm{e}}$ Program Studi Pendidikan Non Formal, Universitas Sultan Ageng Tirtayasa, Banten, Indonesia \\ ${ }^{\mathrm{f}}$ Program Studi Bimbingan dan Konseling, Universitas Sultan Ageng Tirtayasa, Banten, Indonesia \\ ${ }^{\mathrm{g}}$ Program Studi Pendidikan IPA, Universitas Sultan Ageng Tirtayasa, Banten, Indonesia \\ ${ }^{\mathrm{h}}$ Program Studi Akuntansi, Universitas Sultan Ageng Tirtayasa, Banten, Indonesia
}

\begin{abstract}
The purpose and objective of holding a training webinar with the theme of implementing digital marketing in attracting consumer interest in the era of the covid-19 pandemic in community service activities in the Ketapang village is to help people who have difficulties in doing marketing for their products in the era of the covid-19 pandemic where they can use social media by using attractive designs to attract consumers. Government policies such as PPKM during the pandemic often make business owners worry about their business. They are afraid that their business will not go well, because it is important to use social media to market their products to attract consumers, even if not directly.
\end{abstract}

\section{Pendahuluan}

Berdasarkan data tahun 2020 bulan Januari, Desa Ketapang merupakan sebuah Desa yang berada di sebelah timur Kota Tangerang dan berada di Kecamatan Cipondoh, Kota Tangerang. Secara Demografi letak geografis Desa Ketapang terletak diantara: Sebelah utara berbatasan dengan DKI Jakarta sebelah salatan berbatasan dengan Desa Gondrong dan Desa Kenanga, sebelah barat Desa Cipondoh Indah dan sebelah timur Desa Petir, Adapun luas wilayah Desa Ketapang adalah 1080 ha, dengan letak ketinggian di atas permukaan laut sekitar 14 Mdl. Wilayah Ketapang terdiri dari 8 RW dan 45 RT. Adapun jumlah penduduk sebanyak 13.302 jiwa yang terdiri dari 6.578 jiwa Perempuan dan 6.724 jiwa Laki-laki. Adapun jumlah kepala keluarga (KK) 4.278 jiwa, terdiri atas perempuan 1.461 jiwa dan laki-laki 2.815 jiwa. Sarana pendidikan umum yang terdapat di Desa Ketapang terdiri atas TK 6 buah, SD 2 buah, SLTP 2 buah, SLTA 4 buah. Pendidikan agama terdiri atas pondok pesantren 4 buah, Mdr.Ibtidaiyah 2 buah, Tsanawiyah 2 buah, dan Aliyah 2 buah. Untuk sarana kesehatan, terdapat dokter umum 5 orang, dokter gigi 1 orang,

\footnotetext{
* Corresponding author:

E-mail address: 2281180022@untirta.ac.id
} 
dokter spesialis 1 orang, bidan 9 orang, perawat 5 orang, apotek 2 orang dan toko obat 4 orang. Media massa yang berada di Desa Ketapang berupa pesawat telpon 316 buah, pesawat televisi 1.629 buah, pesawat radio, 1.141 buah. Dengan jumlah pemeluk agama mayoritas Islam. Dengan jumlah UMKM toko 5 buah, warung 31, restoran 1 dan warung nasi 9 buah .

Penyebaran pandemi virus corona atau covid-19 di Indonesia membuat sejumlah masyarakat sulit dalam bekerja, apalagi pandemi ini membuat pemerintah memberlakukan kebijakan pembatasan besar-besaran yang biasa kita kenal dengan PSBB (Pembatasan Skala Besar-Besaran) atau PPKM (Perberlakuan Pembatasan Kegiatan Masyarakat). Menurut Presiden Joko Widodo dalam (Covid.goid, 2021) mengatakan akan memperpanjang Pemberlakukan Pembatasan Kegiatan Masyarakat (PPKM) level 4 hingga 2 Agutus 2021, dan diperpanjang kembali menjadi tanggal 9 Agustus 2021 pemberlakuan tersebut diberlakukan untuk wilayah Jawa dan Bali. Kebijakan itulah yang menjadi faktor utama masyarakat kesulitan bertahan hidup karena tidak adanya pemasukan khusunya bagi masyarakat menengah kebawah, di kutip dari (Detikfinance, 2021). Berdasarkan presentase yang di kutip dari katadata.co.id (2021), BI mencatat terdapat 87,5\% atau sekitar 2.600 UMKM yang terdampak negative pandemic Covid-19. Dari data tersebut, 93,2\% terdampak dari sisi penjualan. Kemudian sebanyak 16,2\% UMKM yang terdampak mengalami penurunan penjualan hingga 25\%. Lalu, 40\% UMKM mengalami penurunan penjualan sekitar $25-50 \%, 28,2 \%$ UMKM mengalami penurunan penjualan 51-75\%, dan 15,6\% UMKM penjualannya anjlok di atas 75\%.

Fenomena tersebut di alami di Desa Ketapang, menurut pengamatan kami di Desa Ketapang banyak masyarakat yang memiliki UMKM (Usaha Mikro, Kecil, dan Menengah) seperti kuliner dan konveksi, namun kebijakan pemerintah dalam pemberlakuan PPKM membuat sejumlah pemiliki usaha khawatir akan usahanya. Pada saat pandemik tidak sedikit UMKM yang mengalami krisis usaha. Oleh karena itu penting bagi pelaku UMKM untuk memiliki strategi bertahan sehingga selamat dari krisis akibat pandemic Covid-19. Menurut wawancara yang kami lakukan kepada dua orang pemilik pelaku usaha mereka merasa di era pandemi ini mengalami penurunan omset, lalu mereka juga mengalami kesulitan dalam melakukan pemasaran untuk produk mereka di era pandemi ini. Fenomena itulah yang melatarbelakangi kelompok kami dalam membuat program kerja webinar pelatihan dengan tema Implementasi Digital Marketing Dalam Menarik Minat Konsumen Di Era Pandemi Covid-19. Dalam webinar tersebut memiliki sub tema yaitu kiat-kiat sukses bisnis online dan proses pembuatan konten kreatif. Tujuan pelaksanaan webinar ini adalah untuk membantu masyarakat yang memiliki kesulitan dalam melakukan pemasaran untuk produk mereka di era pandemi covid-19 dimana mereka dapat mengunakan media sosial dengan menggunakan desain yang menarik untuk menarik minta konsumen. Jika hal tersebut tidak segera diatasi maka UMKM di desa ketapang akan mengalami penurunan dalam bidang usaha yang berdampak pada perekonomian di desa tersebut.

\section{Metode}

Dengan fenomena-fenomena yang ada diatas, kami memberikan solusi dengan melakukan metode yaitu kegiatan Webinar Pelatihan dengan tema "Implementasi Digital Marketing Dalam Menarik Minat Konsumen Di Era Pandemi Covid-19 Khususnya Di Desa Ketapang” dengan bentuk kegiatan yang dilakukan berdasarkan himbauan pemerintah dan pihak kampus Universitas Sultan Ageng Tirtayasa membatasi kegiatan KKM ini, maka semua kegiatan KKM dilakukan secara daring begitu pula dengan kegiatan webinar pelatihan ini dengan tema implementasi digital marketing dalam menarik minat konsumen di era pandemi covid-19. Sasaran dari kegiatan webinar pelatihan ini ditujukan untuk masyarakat umum, seluruh warga Desa Ketapang, serta pemilik usaha di seluruh Indonesia. Output dan Outcome dari kegiatan ini adalah 1. Peserta mengetahui pengertian digital marketing, 2. Peserta dapat mengetahui bagaimana cara mengatur saat ingin terjun ke dunia digital marketing, 3. Peserta dapat mengetahui bentuk pemasaran yang tepat bagi mereka (pemula dan perintis usaha), 4. Peserta dapat mengetahui alur pembuatan grafik design dan content writer, 5. Peserta dapat mengetahui langkah-langkah mempersiapkan design visual untuk Konten sosial media, 6. Peserta dapat mengetahui cara menentukan tema konten, 7. Peserta dapat mendapatkan tips branding dan salling, 8. Peserta dapat membuat design produk dengan menggunakan aplikasi adobe photoshop.

Proses kegiatan webinar ini dilaksanakan pada tanggal 07 Agustus 2021 dengan tema "Implementasi Digital Marketing Dalam Menarik Minat Konsumen Di Era Pandemi Covid-19" dengan subtema kiat-kiat sukses bisnis online yang disampaikan oleh Ibu Titis Nistia Sari, S. ST., M. E adapun materi yang disampaikan mengenai: definisi 
digital marketing, transformasi marketing, definisi konsumen digital, peluang dan tantangan digital marketing. Kemudian subtema yang kedua yaitu proses pembuatan konten kreatif yang disampaikan oleh Bapak Bobby Supriyanto dengan materi workflow pekerjaan pembuatan materi kreatif, langkah - langkah membuat konten yang berdampak untuk kesadaran sebuah merk yang kita miliki, menentukan desain visual untuk mendukung konten sosial media dan tutorial mendesain menggunakan photohop. Kegiatan webinar ini diikuti oleh 61 orang. Kegiatan webinar ini dilakukan secara daring melalui Zoom Meeting. Pemberian sertifikat diberikan melalui link google drive dan disebar melalui grup whatsapp.

\section{Hasil dan Pembahasan}

Di era pandemi covid-19 ini banyak masyarakat yang memiliki usaha kecil mengalami kesulitan dan pengurangan dalam segi pendapatan dikarenakan kebijakan pemerintah seperti PPKM, kerena hal ini lah strategi pemasaran sangat diperlukan khususnya kepada pedagang. Menurut Haryanti et al. (2017), Strategi pemasaran adalah suatu rencana pemasaran didalam sebuah perusahaan untuk memperoleh hasil yang optimal. Strategi pemasaran memiliki ruang lingkup yang cukup luas di antaranya adalah strategi menghadapi persaingan, strategi produk, strategi harga, strategi tempat, dan strategi promosi. Permasalahan yang sering terjadi di desa ketapang adalah kesulitan mereka dalam melakukan pemasaran untuk produk UMKM di era pandemi.

Perkembangan teknologi informasi yang pesat menjadi faktor pendukung dalam melakukan pemasaran produk, hal tersebut dapat dilakukan dengan Digital Marketing. Digital marketing menjadi salah satu strategi yang sering digunakan oleh pelaku usaha karena kemampuan baru konsumen dalam mengikuti arus digitalisasi, beberapa perusahaan sedikit demi sedikit mulai meninggalkan model pemasaran konvesional/dan beralih ke pemasaran moderen. Menurut Febriyantoro \& Arisandi (2018), dengan digital marketing komunikasi dan transaksi dapat dilakukan setiap waktu dan bisa di akses ke seluruh dunia, seseorang juga dapat melihat berbagai barang melalui internet, sebagian besar informasi mengenai berbagai produk sudah tersedia di internet, kemudahan dalam pemesanan dan kemampuan konsumen dalam membandingkan satu produk dengan produk lainnya. Dengan adanya strategi pemasaran tersebut dapat menjadi salah satu pilihan strategi yang dapat digunakan di Desa Ketapang untuk meningkatkan UMKM dalam bidang pemasaran produk.

Berdasarkan permasalahan-permasalahan yang dijelaskan diatas, hasil yang didapat pada Webinar Pelatihan dengan tema "Implementasi Digital Marketing Dalam Menarik Minat Konsumen Di Era Pandemi Covid-19 Khususnya Di Desa Ketapang" adalah sebagian masyarakat Desa Ketapang mampu mengetahui pentingnya digital marketing dalam pelaku usaha, karena dalam digital marketing, mereka dapat bentuk pemasaran yang tepat bagi mereka (pemula dan perintis usaha). Lalu sebagian masyarakat Desa Ketapang juga dapat mengetahui langkah-langkah mempersiapkan design visual untuk Konten sosial media, karena dalam webinar ini memberikan pelatihan mengenai cara membuat design visual menggunakan aplikasi Adobe Photoshop.

\section{Kesimpulan}

Berdasarkan kegiatan program kerja yang telah dilakukkan oleh kelompok kkm 102 di Desa Ketapang, Kecamatan Cipondoh, Kota Tangerang, Banten, banyak masyakat ketapang yang memiliki usaha yang mangalami dampak dari kebijakan pemerintah yaitu PPKM. Dengan adanya kegiatan webinar ini bertujuan untuk membantu masyarakat di desa ketapang dalam melakukan pemasaran di era pandemi dengan menggunakan media sosial yang dapat menarik minat konsumen sehingga membuat usaha di desa ketapang dapat meningkat walaupun di masa pandemi covid-19.

\section{Acknowledgements}

Kami mengucapkan terima kasih kepada semua pihak yang pihak yang telah membatantu kami dalam penyusunan jurnal pengabdian ini, diantaranya:

1. Bapak H. Alex Saadon, S Ip., M. M selaku Kepala Desa Ketapang.

2. Bapak Deris Dasmawan, S. E., M. Si selaku Dosen Pembimbing Lapangan. 
3. Ibu Titis Nistia Sari, S. ST., M. E selaku pemateri pertama pada webinar pelatihan ini.

4. Bapak Bobby Supriyanto selaku pemateri kedua pada webinar pelatihan ini.

5. Seluruh anggota kelompok 102 KKM Tematik Desa Ketapang 2021

\section{References}

Febriyantoro, M. T., \& Arisandi, D. (2018). Pemanfaatan Digital Marketing Bagi Usaha Mikro, Kecil Dan Menengah Pada Era Masyarakat Ekonomi Asean. JMD: Jurnal Riset Manajemen \& Bisnis Dewantara, 1(2), 61-76. https://doi.org/10.26533/jmd.v1i2.175

Haryanti, S., Mursito, B., \& Sudarwati. (2017). Analisis Strategi Pemasaran Digital untuk Meningkatkan Penjualan Produk Batik pada PT. Danar Hadi Surakarta. Journal of Chemical Information and Modeling, 53(9), 144-151.

Detikfinance. 2021. 4 Dampak Besar Penerapan PSBB Ketat. Detik. https://finance.detik.com/berita-ekonomibisnis/d-5329533/4-dampak- besar-penerapan-psbb-ketat.

Covid-19. 2021. PPKM Level 4 Diperpanjang Tiga Inmendagri. Satgas Covid. https://covid19.go.id/p/berita/ppkmlevel-4-diperpanjang-tiga-inmendagri.

Victoria, O.V. Hanya 12,5\% UMKM di Indonesia yang Kebal dari Pandemi Covid-19. Katadata. https://katadata.co.id/agustiyanti/finansial/605d9f635fdf7/hanya-12-5-umkm-di-indonesia-yang-kebal-daripandemi-covid-19. 